\title{
ELABORATION OF WINE-BASED GOURMET SAUCES: physicochemical, nutritional and sensory analysis
}

\author{
Jéssica Collares Valladão \\ Camila da Silva Vaz Branco ${ }^{b}$ \\ Elga Batista da Silvac \\ Lenice Freiman de Oliveira ${ }^{d}$
}

\begin{abstract}
The use of wine in the preparation of sauces adds value to this type of culinary preparation, catering for a diverse audience and preferences. The aim of this work to produce wine sauces and determine their acceptability (acceptance test and purchase intention) and physicochemical characteristics. It was fond that the sauces were satisfactory, making the manufacture of the products viable. For the sensory analysis, a hedonic scale was used to assess the color, appearance, aroma, texture and flavor. In the general evaluation, the sensory analysis of the winebased sauces showed satisfactory acceptance, particularly the dry white wine sauce. The production of wine sauces proved to be viable, and may represent an option for those in search of foods with possible health benefits.
\end{abstract}

\section{Keywords:}

Enogastronomy

Healthy eating

Wine sauce 


\section{INTRODUCTION}

Since the 1990s, there has been interest in various issues related to food and human nutrition (Zaneti \& Schneider, 2016). Food products have been developed to cater for these demands, which are relatively recent in the food market, including those related to contemporary gastronomy.

There are countless possibilities for the development of gastronomic products, considering the profiles of various culinary preparations. For example, there are sauces that can be added to dishes such as pasta, meat, poultry, fish and desserts.

Sauce is an ancient culinary preparation, served in the form of broths or seasonings. The word 'sauce' originates from the Latin word mogliu, derived from the verb molliare, which means to moisten. Sauces can be used to braising delicacies, or served as an accompaniment to foods (Rodrigues \& Nunes, 2005), adding flavor, moisture, appearance and texture (Autran, 2004).

Wine contains a set of organic compounds, called phenolic compounds, that are beneficial for human health. Phenol has the chemical formulation $\mathrm{C} 6 \mathrm{H} 5 \mathrm{OH}$ (Morita \& Assumpção, 1972). These compounds are considered very important in oenology, as they directly or indirectly affect in the quality of wines. Grapes contain different types and amounts of phenols. Depending on the maturity, variety, climatic conditions, and other factors, wine may contain a greater or lesser variety and percentage of phenols (Mazza \& Brouillard, 1987).

Red wine has beneficial effects on the body if consumed in moderation. Research has shown shows that drinking red wine helps prevent diseases of old age, such as Alzheimer's (Giada \& Mancini Filho, 2016) and hypertension (Mamede \& Pastore, 2004).

Based on this statement, the aim of this work was to produce wine sauces from different types of wine red and white, with dry and sweet versions of each and determine their acceptability (acceptance test and purchase intention) and physicochemical characteristics.

\section{Theoretical Reference}

Sauces appeared when man first dominated fire, as this was made it possible to cook (Leal, 1998). These products have long been used to preserve foodstuffs, mainly meat, which were marinated in fruit juices (Donel, 1999). Sauces were also used later for salting, seasoning and moistening culinary preparations (Gomes \& Midori, 2002); they can be served hot, cold, in sweet or savory dishes, smooth or with pieces (Autran, 2004).
It has also been demonstrated that in wine-based sauces, the ability of the wine to preserve raw steaks with respect to proliferation of microorganisms, a fact that allows the ability antimicrobial of this type of wine (Kargiotou, Katsanidis, Rhoades, Kontominas, \& Koutsoumanis, 2011). In classic cuisine, artisanal sauces are the highlight, however, in many restaurants the elaborate sauces lost space for the industrialized, due to practicality and the need agility the customer service (Gisslen, 1989). In traditional cuisine, the sauce acts as an element capable of promoting more sophistication to many dishes savory. In terms of preparation techniques, classic sauces are simmered, reduced and then sieved (David, 2000). The most different dishes and types of cuisine aroun the world are milestones in traditional cuisine, wich always seeks in particilar essences, qualities and characteristics, unique in this means of production, seasoning and finally all the legacy left by traditional and knowledge comprehensive to many regions at the same time (Muller, Amaral, \& Remor, 2010).

In addition to the demand for gastronomic products, another trend increasingly most present in the area of food is the predilection for healthy products, that use nutritional quality star ingredients (Peschel, Kazemi, Liebichová, Sarraf, \& Witzel 2019).

Society is gradually increasing food consumption healthier, capable of preventing and treating diseases, in addition to increasing longevity, generating greater product demands derivatives derived from foods. As an example of this statement, highlight the wine, which has been identified as a functional food, that is, capable of reduce the risk of specific illnesses, as well as help to treat them (Moraes \& Locatelli, 2010). Wine is one of the oldest drinks ever consumed, with reports of its consumption more than 7,000 years ago, in the Mediterranean region, being currently an economically important product and a traditional and recognized drink all over the planet (Roese, 2008). It is a drink obtained from fresh and ripe grapes or juice of fresh grape, being biochemically defined as a drink from alcoholic fermentation of glucose and fructose present in the grape by yeasts and then malolactic fermentation, by lactic acid bacteria, with the function of decreasing total acidity (Moraes \& Locatelli, 2010). The wines can be classified according to their type (red, pink and white), class (light, semi-sparkling, carbonated, liqueur, compound, fine and table) and / or sugar content (sweet, medium dry and dry) [Brasil] (1988). The wine stands out due to diuretic function, due to properties as its high potassium concentration, and in the aid of digestion, raising salivation, acid content, and releasing gastric juice, thus, being quite consumption during a meal (Rizzon, Zanuz, \& Manfredini, 1996). The development of a product derived from wine could further increase your consumption, using it in food preparation, enhancing the aforementioned 
effects. It should be noted that the harmonization between wine and food have been widely researched in the years (Echevins, Giboreau, Julien, \& Dacremont, 2019), a fact that can, in a complementary way, encourage studies to elucidate profiles of food products with wine as an ingredient star. As an example of this statement, we mention the possibility of making wine sauces based wine. As they are derivative products, generally handmade, without a standardization of the production process, the physicochemical characterization of sauces also becomes essential, due to the absence of specific data in the literature that provide this information (Valério, Silva, Coelho, Castro, \& Ribeiro, 2014); in addition to sensory analysis, that identify a consumer expectation, techniques occur aim to provide answers to various food properties from the point of view of consumer (Piggott, Simpson, \& Williams, 1998). This characterization it is intended to create a reference data that is used in determining the identity and quality standards of similar gourmet sauces.

\section{MetHOdOLOGY}

The experiment was performed at the Food and Beverage Laboratory of the Applied Social Sciences Institute of the Federal Rural University of Rio de Janeiro (UFRRJ), from November 2018 to April 2019. Samples of dry red wine Santa Carolina, Merlot 2015 vintage, sweet red wine Almadén, Cabernet 2016 vintage, dry white wine Almadén, Varietal 2016 vintage and sweet white wine (without harvest) were used to produce the sauces. The reason for the choose of the wines it's because all of them are easier to find in the market. To develop the technical files, a methodology adapted from Guedes (2014) was used, which described the preparation of a sweet and sour sauce based on xerez wine to accompany pork. All the sauces followed the same technical sheet, changing only the type of wine and the flavor of the powdered broth, being the beef broth used to produce the red wine sauces and the chicken broth for the white ones. For each formulation

Table 1: Formulation of wine sauces

\begin{tabular}{cc}
\hline Ingredients & Quantity \\
\hline Wines & $250 \mathrm{ml}$ \\
\hline Tomato & $50 \mathrm{~g}$ \\
\hline White Onion & $20 \mathrm{~g}$ \\
\hline Garlic & $5 \mathrm{~g}$ \\
\hline Chicken or Beef Broth (Powder) & $30 \mathrm{~g}$ \\
\hline Butter & $10 \mathrm{~g}$ \\
\hline Water & $75 \mathrm{~g}$ \\
\hline
\end{tabular}

was tried thrice. Table 1 shows the formulation of the sauces.

\section{Sauces processing}

The butter was taken to the fire in a pan, letting it partially melt. After that, the chopped onion and the beaten garlic were added to sauté. Posteriorly, the chopped tomato next to the powdered beef broth or powdered chicken broth, both diluted in water $(25 \mathrm{~mL})$, were appended, and finally the wine was added. In the next stage, this mixture was submitted to cooking for 5 minutes for wine reduction. Then, the resulting product was sieved and was taken back to the fire for the addition of corn starch diluted in water $(25 \mathrm{~mL})$, in order to provide a firmer texture to the sauce.

After cooking, the sauces were stored in sterile glass containers by boiling for 20 minutes and sealed with equally sterile lids. The containers were stored at refrigeration temperature until the time of analysis.

\section{Determination of the physicochemical character- istics of the sauces}

Physicochemical analyzes were performed, in triplicate, to identify the patterns of the sauces, since to date, there is no established parameter for the product in Brazilian legislation. For all analyzes mean, standard deviation and coefficient of variation were calculated.

\section{Moisture}

The moisture was estimated by gravimetry in a forced-air oven at $105^{\circ} \mathrm{C}$, until reaching constant weight, following the methodology of the Adolfo Lutz Institute (1985), in which analytical balance (Bioprecisa ${ }^{\circledR}$, model FA2104N) was used.

\section{Protein}

The protein content was measured using the Kjeldahl method, calculating the amount of protein nitrogen present in the sample using the factor 6.25, according to the AOAC (2006), using the digester (Tecnal ${ }^{\circledR}$, model TE-007MP) and the hydrogen distiller (Tecnal ${ }^{\circledR}$, model TE-0363).

\section{Lipids}

The lipids were obtained by gravimetry using a Soxhlet extractor (Marconi ${ }^{\circledR}$, model MA-487) and petroleum ether was used as the solvent, according to the Adolfo Lutz Institute (1985). 


\section{Total Soluble Solids ( ${ }^{\circ}$ Brix)}

Total soluble solids (TSS) were determined directly in the sauce samples, by refractometry (Adolfo Lutz Institute, 1985); using a portable refractometer (Portable ${ }^{\circledR}$, model 107) and the results were expressed in ${ }^{\circ}$ Brix. The amount of soluble solids is the total of all dissolved solids.

\section{Ash}

The ash content was obtained by the gravimetric method after burning in a muffle furnace (SPLabor ${ }^{\circledR}$, model SP-1200) at $550^{\circ}$, until reaching constant weight (Adolfo Lutz Institute, 1985).

\section{Total carbohydrates}

The carbohydrates were estimated by subtracting the results of the above-described items from $100 \%$ of sample.

\section{Total caloric value (TCV)}

The total caloric value (TCV) was reached through the formula (\% Ptn $\left.4+\% \mathrm{HC}^{\star} 4\right)$, according to Carvalho (2002).

\section{Sensory acceptance test}

The sensory acceptance test was performed at the Laboratory of Food and Beverage of the Institute of Applied Social Sciences (ICSA) of Federal Rural University of Rio de Janeiro (UFRRJ). The analysis was accomplished one day after the sauces production, under controlled environmental conditions, using white light lamps and air conditioning at a temperature of $25^{\circ} \mathrm{C}$. The red wine sauces were served accompanied by a piece of grilled beef, while the white wine sauces were served accompanied by a piece of grilled chicken. The chicken and beef were sliced into fillet, with each piece containing $15 \mathrm{~g}$, were seasoned with salt and lemon drops (only the chicken) and were freshly fried in sunflower oil.

The wine sauces were submitted to a sensory evaluation using 52 untrained consumers, regardless of age or gender. The samples were first visualized and then tasted. A 9-point structured hedonic scale, with scores from 9 (= liked extremely) to 1 (= disliked extremely), was used to evaluate color, aroma, flavor, texture and overall appearance, respectively. The purchase intention was also evaluated, through structured scale, ranging from "I certainly would buy" to "I certainly wouldn't buy", according to the methodology described by Stone and Sidel (1993) and Meilgaard, Carr and Civille (1999). The attributes averages related to the preference of each assessed sample were complemented by the descriptive statistical analysis of the respective standard deviations and coefficients of variation.

\section{Results ANd Discussion}

The physicochemical results of wine sauces are shown in Table 2. The addition of different wines did not pro-

Table 2: Physicochemical parameter of wine sauces

\begin{tabular}{ccccccccc}
\hline \multirow{3}{*}{ Evaluated Parameter } & \multicolumn{3}{c}{ Red Wine } & \multicolumn{3}{c}{ White Wine } \\
\cline { 2 - 9 } & \multicolumn{2}{c}{ Dry } & \multicolumn{2}{c}{ Sweet } & \multicolumn{2}{c}{ Dry } & \multicolumn{2}{c}{ Sweet } \\
\cline { 2 - 9 } & Av.+S.D. & C.V. & Av.+S.D. & C.V. & Av.+S.D. & C.V. & Av.+S.D. & C.V. \\
\hline Moisture (\%) & 83.72 & 0.54 & $82.04 \pm 0.10$ & 0.13 & $85.36 \pm 1.0$ & 1.24 & $82.64 \pm 0.19$ & 0.23 \\
\hline Protein (\%) & $0.97 \pm 0.0$ & 0.00 & $0.88 \pm 0.05$ & 5.94 & $0.93 \pm 0.00$ & 0.08 & $0.84 \pm 0.04$ & 5.38 \\
\hline Lipids (\%) & $8.06 \pm 0.34$ & 0.26 & $8.39 \pm 0.28$ & 3.36 & $8.17 \pm 0.12$ & 1.43 & $7.61 \pm 0.53$ & 7.01 \\
\hline TSS ('Brix) & $14 \pm 0.0$ & 0.00 & $12 \pm 0.0$ & 0.0 & $12 \pm 0.0$ & 0.0 & $12 \pm 0.0$ & 0.0 \\
\hline Ash (\%) & $1.05 \pm 0.0$ & 7.99 & $1.37 \pm 0.00$ & 3.22 & $1.06 \pm 0.01$ & 1.10 & $1.18 \pm 0.01$ & 0.46 \\
\hline Carbohydrates(\%) & $6.22 \pm 0.73$ & 11.75 & $7.31 \pm 0.35$ & 5.72 & $4.45 \pm 1.03$ & 16.52 & $7.72 \pm 0.71$ & 11.38 \\
\hline TCV (Kcal) & $159.79 \pm 2.9$ & 1.89 & $140.79 \pm 1.6$ & 1.14 & $129.54 \pm 4.1$ & 3.17 & $142.25 \pm 2.8$ & 1.98 \\
\hline
\end{tabular}

$A v .=$ average, S.D. = standard deviations, C.V. = coefficients of variation. 
vide great influence between the variables moisture, protein, lipids, total soluble solids and ashes.

For total carbohydrates variable, the sauce with dry white wine showed results below the other sauces analyzed. This parameter influenced its total caloric value, considering the energetic contribution of carbohydrates, also lower than the other sauces.

As it is a normally handmade product, no data were obtained in the literature on the physicochemical parameters to be respected for the wine sauces production. According to resolution RDC 276 [Brasil] (2005), which regulates standards and basic quality attributes of spices, seasonings and sauces, the physicochemical characteristics and their acceptable values have not been defined. Therefore, this lack of data makes it impossible to compare the values reached in this study with values defined by legislation or other scientific studies.

The protein values estimated are similar to those described by Fonseca (2008), who formulated salad sauces with minas frescal cheese, since the sauces are considered low protein products. The same author obtained relatively lower values of total carbohydrates and TCV, a justified result, because in the present study corn starch was used as an emulsifier, a compound formed basically by carbohydrates.

In the four different sauces were identified discrete values of ${ }^{\circ} \mathrm{Brix}$ and ash, a result that was mainly influenced by the non-inclusion of salt at the preparation time, due to the products contain only the salt contained in the chicken or beef broth. Valério et al. (2014), in an experiment with pepper sauce formulation, it was identified that the increased salt concentration in the sauce raised the levels of ash and ${ }^{\circ} \mathrm{Brix}$, as the authors found similar values to those observed in the present study, when 0.46 to $1.27 \%$ of salt were used.

The variable moisture did not present profound differences between the samples. This results corroborates those reported by Nogueira, Vieira, Pinto, Pinto and Ramos (2016), in an experiment with preparation of chili pepper sauces, since them were made on a liquid basis without creaminess, justifying the elevated moisture values.

Regarding the sensory analysis, the results described in tables 3 and 4 show that the dry white wine sauce was considered the most satisfactory for the consumers. This outcome may have been influenced by the more pleasant (less intense) taste of the white wine sauce, in relation to red wine, since several tasters did not approved the stronger flavor of red wine in the sauce, which possibly influenced the results.

Table 3: Sensory acceptance parameter of wine sauces

\begin{tabular}{|c|c|c|c|c|c|c|c|c|}
\hline \multirow{3}{*}{$\begin{array}{c}\text { Evaluated Parame- } \\
\text { ter }\end{array}$} & \multicolumn{4}{|c|}{ Red Wine } & \multicolumn{4}{|c|}{ White Wine } \\
\hline & \multicolumn{2}{|c|}{ Dry } & \multicolumn{2}{|c|}{ Sweet } & \multicolumn{2}{|c|}{ Dry } & \multicolumn{2}{|c|}{ Sweet } \\
\hline & Av.+S.D. & C.V. & Av.+S.D. & C.V. & Av.+S.D. & C.V. & Av.+S.D. & C.V. \\
\hline Color & $7.73 \pm 1.48$ & 0.19 & $7.54 \pm 1.41$ & 0.18 & $7.69 \pm 1.32$ & 0.17 & $7.29 \pm 1.26$ & 0.17 \\
\hline Aroma & $6.82 \pm 1.81$ & 0.27 & $6.71 \pm 1.54$ & 0.23 & $7.25 \pm 1.70$ & 0.23 & $6.78 \pm 1.60$ & 0.23 \\
\hline Flavor & $6.86 \pm 1.98$ & 0.29 & $6.52 \pm 1.53$ & 0.23 & $7.85 \pm 1.32$ & 0.17 & $7.56 \pm 1.33$ & 0.17 \\
\hline Texture & $7.07 \pm 1.96$ & 0.28 & $6.94 \pm 1.61$ & 0.23 & $7.63 \pm 1.64$ & 0.21 & $7.21 \pm 1.61$ & 0.22 \\
\hline Overall Appearance & $7.35 \pm 1.61$ & 1.22 & $7.12 \pm 1.44$ & 0.20 & $7.78 \pm 1.19$ & 0.15 & $7.20 \pm 1.57$ & 0.21 \\
\hline
\end{tabular}

Av. = average, S.D. = standard deviations, C.V. = coefficients of variation.

Source: Elaborated by the authors. 
According to Gibson and Newsham (2018) depending on the composition of the ingredients, the sauces can convey a range of varied flavors, which will influence their acceptance by the consumer. In the sensory evaluation of soy sauces made with an enzymatic hydrolyzate Ruan, Ju, Zhan and Hou (2022) observed that umaminess and bitterness (which make up the flavor) were characteristics that also influenced the analysis of the sensory panel.

Table 4: Purchase intention parameter of wine sauces

\begin{tabular}{c|c|c|c|c}
\hline \multirow{2}{*}{ Purchase Intention } & \multicolumn{2}{|c|}{ Red } & \multicolumn{2}{c}{ White } \\
\cline { 2 - 5 } & Dry & Sweet & Dry & Sweet \\
\hline I certainly would buy & 16 & 4 & 27 & 15 \\
\hline I probably would buy & 17 & 14 & 10 & 13 \\
\hline I Maybe would buy & 7 & 15 & 8 & 18 \\
\hline $\begin{array}{c}\text { I probably wouldn't } \\
\text { buy }\end{array}$ & 7 & 15 & 6 & 5 \\
\hline $\begin{array}{c}\text { I certainly wouldn't } \\
\text { buy }\end{array}$ & 5 & 4 & 1 & 1 \\
\hline \begin{tabular}{c} 
Total tasters \\
\hline
\end{tabular} & 52 & 52 & 52 & 52 \\
\hline
\end{tabular}

Source: Elaborated by the authors.

Moreover, the dry white wine sauce was presented the lowest amount of total carbohydrates, which resulted in less emulsification and, consequently, a less creamy texture. According to the tasters, this characteristic was considered positive and it favored the best rating for this sauce, especially for this attribute.

Rognsa, Pertesen, Rathe and Misje (2017) compared the effects of adding four white wines (Chardonnay, Riesling, Sauvignon blanc and a blended wine) to the hollandaise sauce (made with yolks, butter, lemon juice and salt) on the acceptance of eight products created. The outcomes showed the level of wine reduction (which in this research was $51 \%$ in relation to the original wine moisture) to be added is a more important attribute to influence the flavor of the sauce than the type of wine.

All these factors contributed to the dry white wine sauce obtained the best rating in the overall appearance variable, which resulted in a high product acceptance, since $52 \%$ of people stated "I certainly would buy" this sauce and only $2 \%$ of people stated "I certainly wouldn't buy" this sauce, the most satisfactory result (Figure 1).

According to Paulsen, Ueland, Nilsen, Öström and Hersleth (2012), who evaluated varied combinations of sauces to accompany salmon samples, it was reported that sauces are important in the acceptance of food products, as this blend can cause sensory interactions that alter the overall impression of the meal. Based on this statement, the combination of white and red wine sauces developed in the present study, associated with beef and chicken samples, directly influenced the results of purchase intention test.

Figure 1 - Graphics show the results regarding the purchase intention test

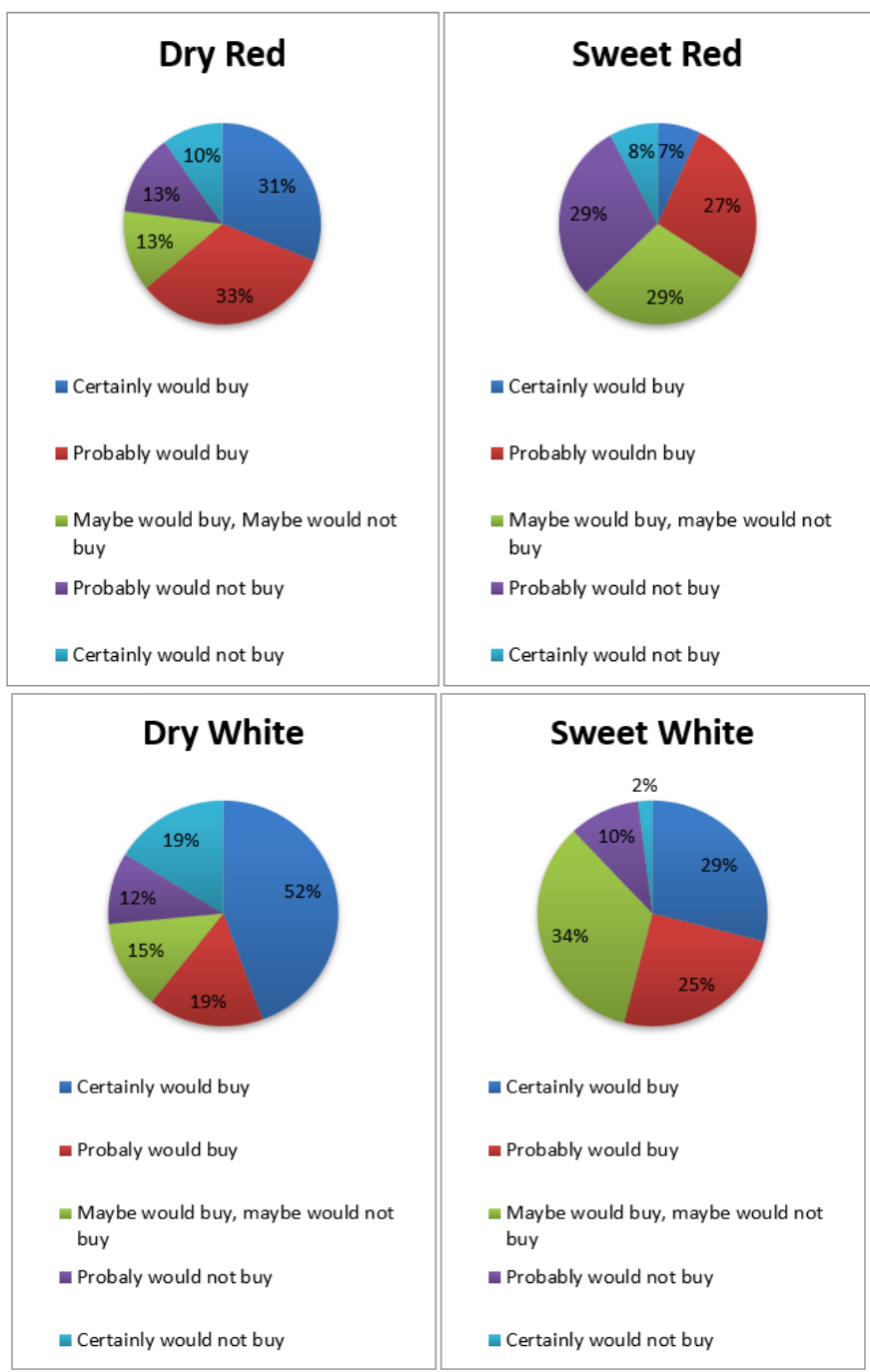

Source: Elaborated by the authors.

\section{CONCLUSION}

The results obtained it is possible to conclude that in the general evaluation, the study of sensory analysis of the sauces based on wine showed satisfactory acceptance with all four sauces obtaining scores above six. In addition, the four products showed relevant results of purchase intention.

Although oenology has been studied a long time, there is still some difficulty to find research related to sauces 
based on wines. Knowing the importance and possible benefits of the drink, this article aims to add new products on the market, mainly for the restaurant menu. Either, encouraging the gastronomic and hospitality majors colleges.

The production of wine sauces proved to be viable and may represent an option for consumers looking for foods with new flavors and may have functional potential for health.

\section{REFERENCES}

Association Of Official Analytical Chemistry - AOAC. (2006). Official methods of analysis of the Association of Official Analytical Chemistry. 18 th ed. Arlington.

Autran, M. (2004). Gastronomia e segurança alimentar: Módulo de produção de alimentos: técnicas culinárias e princípios básicos.

Brasil. (1998). Ministério da Agricultura, Pecuária e Abastecimento. Aprova a Norma referente à complementação dos Padrões de Identidade e Qualidade do Vinho. Portaria $n^{\circ} 229$, de 25 de outubro de 1988. Diário Oficial da União, de 31 de outubro de 1998

Brasil. (2005). Ministério da Saúde. Agência Nacional de Vigilância Sanitária. Resolução RDC n²76, de 22 de setembro de 2005. Aprova o Regulamento técnico para especiarias, temperos e molhos. Diário Oficial da União, de 23 de setembro de 2005

Carvalho, H. H. (2002). Alimentos: métodos físicos e químicos de análise. Porto Alegre: Ed. Universidade/UFRGS

David, E. (2000). Cozinha regional francesa. São Paulo: Companhia das Letras.

Donel, E. O. (1999). Passaporte do Gourmet - Um mergulho na gastronomia francesa. Rio de Janeiro: Ediouro.

Echevins, A., Giboreau, A., Julien, P., \& Dacremont, C. (2019). From expert knowledge and sensory science to a general model of food and beverage pairing with wine and beer. International Journal of Gastronomy and Food Science, (17),100-144.

Fonseca, V.C. (2008). Elaboração de molho para salada com soro de queijo minas frescal estabilizado por combinações ternárias de alginato de propileno glicol, goma xantana e carboximetilcelulose. Dissertação Univesidade Federal do Paraná (UFPR). Disponível: https://acervodigital.ufpr.br/ handle/1884/14218

Giada, M. L. R., \& Mancini Filho, J. (2006). Importância dos compostos fenólicos da dieta na promoção da saúde humana. Publicatio UEPG: Ciências Biológicas e da Saúde,12(4), 7-15.
Gibson, M. \& Newsham, P. (2018). Chapter 15 - Sauces. Food Science and the Culinary Arts.

Gisslen, W. (1989). Professional cooking. 2 Ed. Wiley Copyright.

Gomes, E. \& Midori, L. (2002). Molhos com azeite de oliva espanhol: 365 receitas - uma para cada dia do ano. Editora C2.

Guedes, E. (2014). Sabores do mundo. São Paulo: Planeta.

Instituto Adolfo Lutz. (1985). Normas analíticas: métodos químicos e físicos para análise de alimentos. 2. ed. São Paulo.

Kargiotou C. Katsanidis, E. Rhoades, J. Kontominas, M. \& Koutsoumanis, K. (2011). Efficacies of soy sauce and wine base marinades for controlling spoilage of raw beef. Food Microbiology, 28(1), 158163.

Leal, M.L.M.S. (1998). A História da gastronomia. p.144 Rio de Janeiro: Ed. Senac.

Mamede, M. E. O., \& Pastore, G. M. (2004). Compostos fenólicos do vinho: estrutura e ação antioxidante. B. CEPPA, 22(2), $233-252$

Mazza, G., \& Brouillard, R. (1987). Recent developments in the stabilization of anthocyanins in food products. Food Chemistry, 25(3), 207-225.

Meilgaard, M.C., Carr, B.T., \& Civille, G.V. (1999). Sensory evaluation techniques. CRC press, 3rd edition.

Moraes, V., \& Locatelli, C. (2010). Vinho: uma revisão sobre a composicão química e benefícios à saúde. Evidência, 10(1-2), 57-68.

Muller, S. G., Amaral, F. M., \& Remor, C. A. (2010). Alimentação e cultura: preservação da gastronomia tradicional. Anais do VI Seminário de Pesquisa em Turismo do Mercosul. Caxias do Sul.

Nogueira, B.A., Vieira, E.N.R., Pinto, C.L.O., Pinto, C.M.F. \&Ramos, A.M (2016). Caracterização físicoquímica de molho de pimenta malagueta (capsicum frutensens I.) processado de acordo com as boas praticas de fabricação. Anais do XXV Congresso Brasileiro de Ciência e Tecnologia de Alimentos: Alimentação: A Árvore que Sustenta a Vida, Gramado.

Paulsen, M. T. Ueland, $\varnothing$. Nilsen, A. N Öström, Å., \& Hersleth, M. (2012). Sensory perception of salmon and culinary sauces - An interdisciplinary approach. Food Quality and Preference, 23(2), 99 $-109$.

Peschel, A. O., Kazemi, S., Liebichová, M., Sarraf, S. C. M. \& Witzel J. A. (2019). Consumers' associative networks of plant-based food product communications. Food Quality and Preference, 75, 145156.

Piggott, J.R., Simpson, S.J., \& Williams, S.A.R. (1998) Sensory analysis. International Journal of Food Science and Technology, 33, p. 7-18

Rizzon, L.A.; Zanuz, M.C., \& Manfredini, S. (1996). Como elaborar vinho de qualidade na pequena propriedade. 2. ed. Bento Gonçalves: Embrapa. 
Rodrigues, D., \& Nunes, F. (2005). Larousse Dicionário da Língua Portuguesa Mini, (Coord.). 1.ed. São Paulo: Larousse do Brasil.

Roese, M. (2008). O mondovino de cabeça para baixo: As transformações no mercado internacional do vinho e o novo empresariado vinícola. Revista Sociologia Política, 16(31), 71-83.

Rognsa, G. H., Pertesen, M. A., Rathe, M., \& Misje, K.-E. (2017). From wine to hollandaise sauce: Does the nature of the wine or wine reduction influence sensory attributes? International Journal of Gastronomy and Food Science, 9, 75-87.

Ruan, L., Ju, Y., Zhan, C., \& Hou, L. (2022). Improved umami flavor of soy sauce by adding enzymatic hydrolysate of low-value fish in the natural brewing process, LWT, 155(1),112911.

Stone, H., \& Sidel, J. L. (1993). Sensory evaluation practices. San Diego: Academic.

Valério, M.F.R.V. Jr., Silva, F.D., Coelho, N.R.A., Castro, E.M.O., \& Ribeiro, H.K.Q. (2014). Avaliação de parâmetros físico-químicos de molho de pimenta artesanal. Revista EVS-Revista de Ciências Ambientais e Saúde, 41(1), 116-127.

Zaneti, T. B., \& Schneider, S. (2016). A conversa chegou à cozinha: um olhar sobre o uso de produtos agroalimentares singulares na gastronomia contemporânea. Revista Mundi Meio Ambiente e Agrarias, 1(1), 1-27. 